considerably weaker, as the stain (a spirit varnish) fills the pores and prevents the penetration of the adhesive. It is in complete accord with this explanation that the diminution of strength is less marked with a very porous wood, like deal, than with a closer grained one, like walnut.

For the second kind of joint, that between smooth, non-porous surfaces, the authors postulate some specific action between material and adhesive, and refer to Hardy's views on lubrications. They arrive at the conclusion that any. liquid which wets the surfaces and can somehow be transformed into a solid will act as an adhesive for these surfaces. As soon as the statement is put in this form, it would seem to follow quite naturally from considerations of continuity, which does not lessen its novelty or importance. Very remarkable examples of such 'specific' joints are given; e.g. shellac joints between metal surfaces with a tensile strength of more than two tons per sq. in. Space does not permit more detailed discussion of the paper, which will be read with profit not only by those interested in adhesives, but also by any one who derives pleasure from seeing a complex problem attacked by the whole armoury of research.

Prof. Schryver briefly describes his attempts to isolate a pure standard gelatin or, incidentally, to decide whether a body of uniform composition answering to this description exists; the results are not conclusive. Dr. J. C. Kernot and Miss N. E. Speer have achieved a result of technical and economic interest by producing from suitably treated fish skins a glue quite free from " an ancient and a fish-like smell," such as in ordinary fish glues is disguised-or, as sensitive people might say, accentuated-by various additions. The same authors in another paper suggest improvements in the manufacture of bone glue. Appendix $\mathrm{V}$. deals with the mechanical tests of adhesives for timber used by the Royal Aircraft Establishment; the general conclusion is reached that the causes of the large variations in the results of timber tests remain obscure, and that "until the degree of these variations has been reduced the present forms of test-picce are unsuitable for experimental or even inspection purposes."

Readers of the report will learn with regret, though without surprise, that important investigations on the manufacture of glue have had to be abandoned owing to lack of financial support from manufacturers-a position which is perhaps explained, though scarcely justified, by the great fall in the price of glue.

E. $\mathrm{H}$.

\section{Herrings along the Baltic Coast of Sweden.}

IN Publications de Circonstance of the Conseil Permanent International pour l'Exploration de la Mer, No. 89 , Chr. Hessle surveys the herring investigations which have been carried on during the past few years along the Baltic coast of Sweden. Nets, both drifting and anchored, land-seines, and big traps are all used for the fishery, but the main part of the total catch is fished by nets. Although the bulk of the fish is landed between July and November, considerable quantities are taken during the winter and early spring. Ice on the water is a severe hindrance to the net fishery during the colder months, and in some places it may put a stop to fishing when, by all evidence, herrings are still present. In the archipelagos nets are sometimes used actually under the ice.

Baltic herrings are characterised by their small size, the low average number of vertebræ, and of the keeled scales behind the ventral fins. In contrast to these, the average number of the first vertebra with closed hæmal arches is rather high. Both autumn-spawning and spring-spawning herrings occur, the former being of the greater economic value. Catches of autumnspawners nearly always contain a percentage of spring-spawners, the proportion varying with the season and from year to year. In these catches of mixed fish the spring-spawners are generally smaller in size. This is due partly to the greater percentage of smaller fishes among the spring-spawners, but also to the fact that the rate of growth of the springspawners is inferior. In both classes the rate of growth is exceedingly slow after the second or third year. Spawning would seem to occur in the same places for both autumn and spring fish, the former spawning at a temperature of $\mathrm{II}^{\circ}-\mathrm{I}_{4}^{\circ}$, and the latter at $6^{\circ}-10^{\circ}$.

In the innermost parts of the archipelagos, and especially in the fjords which penetrate deep into the country of the Middle Baltic, there is a fishery which is based on stationary local races in waters so closed and isolated that sea herring do not enter them. The size and rate of growth of these isolated fjord herrings show a very great variability. Gudingen and Gamlebyviken are two fjords separated only by a narrow strip of land: in Gudingen the rate of growth is quite normal, but in Gamlebyviken sexually ripe fish of only Io $\mathrm{cm}$. in length have been taken.

Along the coast of the Gulf of Bothnia herrings are caught in traps, fishing commencing as soon as the ice breaks up in the spring, and lasting until midsummer. The bulk of these "ice herring' are springspawners, and a typical feature of the catches is the great number of remarkably large fish which show a peculiar mixture of characters and habits typical of one or another of the races previously dealt with. Altogether Hessle has provided us with a most interesting and instructive paper.

\section{University and Educational Intelligence.}

ABERYSTWYTh.-Dr. W. Robinson, senior lecturer in the department of cryptogamic botany in the University of Manchester, has been appointed to the chair in botany in University College, Aberystwyth, in succession to Prof. Lloyd Williams, who retires under the age limit in September.

CAMBridge. - The University Commissioners have published a number of regulations that they have made for bringing into action next term the new statutes governing the General Board and the various faculty Boards. They have also published further regulations which they propose to make-after discussion by the Senate-on the election of members of the Council, degree committees, the Buildings Syndicate, and University finance. The chief point on which discussion is likely to take place is the proposal that members of the Council shall be elected by the method of the single transferable vote. So far as the election of ordinary members of the Regent House is concerned, where four members are elected at a time, this provision is probably suitable, as it will ensure representation on the Council of different groups of electors. It is doubtful, however, whether this method secures the most effective result in the case of the election of the other two groups- $(a)$ heads of colleges, and $(b)$ professors and readers. Here only two members are elected at a time in each class. So far as University politics is divided into two fairly even parties, this method generally. means the election of one candidate from each party-not by any means necessarily the best way of electing an executive body.

Mr. A. Hopkinson, Emmanuel College, has been reappointed demonstrator in anatomy.

No. 2965 , VOL. II 8$]$ 